\title{
Article \\ Effect of Clay, Soil Organic Matter, and Soil pH on Initial and Residual Weed Control with Flumioxazin
}

\author{
Calvin F. Glaspie ${ }^{1}$, Eric A. L. Jones ${ }^{2}{ }^{\circledR}$, Donald Penner ${ }^{1}$, John A. Pawlak ${ }^{3}$ and Wesley J. Everman ${ }^{2, *}$ \\ 1 Department of Crop and Soil Sciences, Michigan State University, East Lansing, MI 48824, USA; \\ calvin.glaspie@msu.edu (C.F.G.); Donald.Penner@msu.edu (D.P.) \\ 2 Department of Crop and Soil Sciences, North Carolina State University, Raleigh, NC 27695, USA; \\ eajone22@ncsu.edu \\ 3 Valent U.S.A., P.O. Box 8025, Walnut Creek, CA 94596, USA; John.Pawlak@valent.com \\ * Correspondence: Wesley_Everman@ncsu.edu
}

Citation: Glaspie, C.F.; Jones, E.A.L.; Penner, D.; Pawlak, J.A.; Everman, W.J. Effect of Clay, Soil Organic Matter, and Soil $\mathrm{pH}$ on Initial and Residual Weed Control with Flumioxazin. Agronomy 2021, 11, 1326. https://doi.org/10.3390/ agronomy11071326

Received: 6 June 2021

Accepted: 25 June 2021

Published: 29 June 2021

Publisher's Note: MDPI stays neutral with regard to jurisdictional claims in published maps and institutional affiliations.

Copyright: (c) 2021 by the authors. Licensee MDPI, Basel, Switzerland. This article is an open access article distributed under the terms and conditions of the Creative Commons Attribution (CC BY) license (https:// creativecommons.org/licenses/by/ $4.0 /)$.

\begin{abstract}
Greenhouse studies were conducted to evaluate the effects of soil organic matter content and soil $\mathrm{pH}$ on initial and residual weed control with flumioxazin by planting selected weed species in various lab-made and field soils. Initial control was determined by planting weed seeds into various lab-made and field soils treated with flumioxazin $\left(71 \mathrm{~g} \mathrm{ha}^{-1}\right)$. Seeds of Echinochloa crus-galli (barnyard grass), Setaria faberi (giant foxtail), Amaranthus retroflexus (redroot pigweed), and Abutilon theophrasti (velvetleaf) were incorporated into the top $1.3 \mathrm{~cm}$ of each soil at a density of 100 seeds per pot, respectively. Emerged plants were counted and removed in both treated and non-treated pots two weeks after planting and each following week for six weeks. Flumioxazin control was evaluated by calculating percent emergence of weeds in treated soils compared to the emergence of weeds in non-treated soils. Clay content was not found to affect initial flumioxazin control of any tested weed species. Control of A. theophrasti, E. crus-galli, and S. faberi was reduced as soil organic matter content increased. The control of $A$. retroflexus was not affected by organic matter. Soil pH below 6 reduced flumioxazin control of $A$. theophrasti, and $S$. faberi but did not affect the control of $A$. retroflexus and E. crus-galli. Flumioxazin residual control was determined by planting selected weed species in various lab-made and field soils $0,2,4,6$, and 8 weeks after treatment. Eight weeks after treatment, flumioxazin gave $0 \%$ control of $A$. theophrasti and $S$. faberi in all soils tested. Control of $A$. retroflexus and Chenopodium album (common lambsquarters) was $100 \%$ for the duration of the experiment, except when soil organic matter content was greater than $3 \%$ or the soil pH 7 . Eight weeks after treatment, $0 \%$ control was only observed for common A. retroflexus and C. album in organic soil (soil organic matter $>80 \%$ ) or when soil $\mathrm{pH}$ was above 7 . Control of $A$. theophrasti and S. faberi decreased as soil organic matter content and soil $\mathrm{pH}$ increased. Similar results were observed when comparing lab-made soils to field soils; however, differences in control were observed between lab-made organic matter soils and field organic matter soils. Results indicate that flumioxazin can provide control ranging from $75-100 \%$ for two to six weeks on common weed species.
\end{abstract}

Keywords: adsorption; efficacy; flumioxazin; herbicide bio-assay; persistence; weed management

\section{Introduction}

Interactions between a soil-applied herbicide and soil medium are complex. A relative equilibrium is reached soon after the application of a herbicide to soil [1,2]. The portion of herbicide that is not sorbed to the soil particle surface is generally considered available for weed control [3,4]. Therefore, if herbicide adsorption increases, subsequent weed control decreases. The amounts and types of particles in the soil and the soil's pH can greatly affect herbicide adsorption. Herbicide adsorption in soil is often evaluated by deriving a $K_{d}$ value, a measure of the amount of herbicide in solution to herbicide adsorbed to soil particles [2]. A $K_{d}$ value is often adjusted for soil organic matter (SOM) due to the magnitude of its role in herbicide binding $[2,5,6]$. Soil organic matter can differ greatly 
in functional group type and abundance, depending on the origin of the SOM, soil $\mathrm{pH}$, climate, and the microbial community [7,8]. Soil organic matter is not the sole sorbent for many herbicides. Soil clay particles, due to their net negative charge, can interact with herbicides in many ways. Clay is reported as the major adsorption surface for certain herbicides [5].

Flumioxazin, a non-ionic protoporphyrinogen oxidase-inhibiting herbicide (PPO, EC 1.3.3.4, herbicide group [HG] 14), is labeled for preemergent use in many crops, including alfalfa (Medicago sativa L.), cotton (Gossypium hirsutum L.), peanuts (Arachis hypogaea L.), potato (Solanum tuberosum L.), soybeans (Glycine max L.), and wheat (Triticum aestivum L.) $[9,10]$. Flumioxazin has been used widely in crop systems to manage acetolactate synthase (ALS, EC 2.2.1.6, HG 2), photosystem II (PSII, EC 1.10.3.9, HG 5), 5-enolpyruvylshikimate synthase (EPSPS [glyphosate], EC 2.5.1.19, HG 9), 4-hydroxyphenylpyruvate dioxygenase-inhibiting (HPPD, EC 1.13.11.27, HG 27), herbicide-resistant, and herbicidesusceptible weed species due to its different sites of action [11-14]. Flumioxazin control has been shown to vary between and within studies on different weed species [15-19]. While the species were similar in each experiment, the soil types in which flumioxazin was applied greatly differed. Observed differences in initial and residual weed control with flumioxazin could be due to variations in the chemical and physical properties of the soil to which it is applied.

Non-ionizable herbicides such as flumioxazin form relatively few associations with soil particles [20,21]. Adsorption of non-ionizable herbicides to soil particles is mainly attributed to hydrophobic binding, which is the result of a decrease in entropy due to partitioning of the hydrophilic herbicide in the hydrophobic regions of soil $[20,22]$. Soil organic matter and the interlayer of clays provide the conditions necessary to adsorb flumioxazin due to the hydrophobicity of the particles. However, SOM and clay particles are, to some degree, subject to alterations in chemical and physical structure due to solution $\mathrm{pH}$. The effects of soil $\mathrm{pH}$ on SOM can be diverse and are due to the effects of speciation on SOM functional groups [22,23]. Ferreira et al. [24] found SOM to increase in hydrophobicity at soil $\mathrm{pH}$ values lower than five, which could increase flumioxazin adsorption.

Batch equilibrium and field experiments have been conducted to evaluate the adsorption of flumioxazin. Researchers found the adsorption of flumioxazin to be correlated with SOM and certain types of clay particles [1,25]. These experiments focused extensively on herbicide adsorption, with weed control effects only implied [26]. Field studies are often conducted to determine the effect of soil type on weed control but are complicated due to soil variations within a plot, differences in weather, spatial variation in weed population and density, and a lack in range of soil parameters tested [4,22,27]. Experiments conducted in controlled environments with various soils could provide insight into the initial control and length of pervasive weed control when treated with flumioxazin. Thus, the objective of the experiment was to determine the initial and residual control of flumioxazin as influenced by various soil characteristics on select weed species. The hypotheses of the experiment were that soil $\mathrm{pH}$ would have no effect while increasing clay SOM content will reduce flumioxazin initial and residual control due to the non-ionic properties of the herbicides.

\section{Materials and Methods}

\subsection{Flumioxazin Initial Control}

Three separate greenhouse experiments were conducted at Michigan State University to investigate the effect of clay content, $\mathrm{SOM}$, or soil $\mathrm{pH}$ on flumioxazin efficacy. The studies were arranged in a randomized complete block design with a factorial arrangement of treatments, four replications, and repeated in time. Experimental factors included: three soil characteristics, four weed species, and two herbicide treatments. Base soil components utilized in the study were collected from the top $13 \mathrm{~cm}$ of respective field soils in uniform areas with no history of flumioxazin application. Soil components were autoclaved prior to use to ensure soil sterility as flumioxazin is susceptible to rapid microbial degradation [28]. 
Soil particle size distribution, $\mathrm{pH}$, cation exchange capacity (CEC), and SOM content were determined for each soil used (Table 1).

Table 1. Properties of the soils used to evaluate the efficacy of flumioxazin on Echinochloa crus-galli, Setaria faberi, Amaranthus retroflexus, and Abutilon theophrast ${ }^{\text {a }}$.

\begin{tabular}{ccccccc}
\hline Soil & Sand & Silt & Clay & SOM & pH & CEC \\
\hline Sand & 97.7 & 0.07 & 2.1 & 0.1 & 10 & 0.6 \\
10\% Clay & 88.2 & 0.4 & 11.2 & 0.2 & 9.3 & 1.5 \\
20\% Clay & 78.8 & 0.6 & 20.4 & 0.2 & 9 & 2.9 \\
30\% Clay & 66.5 & 2.6 & 30.7 & 0.2 & 8.8 & 3.7 \\
40\% Clay & 56.2 & 3.4 & 40.2 & 0.2 & 8.7 & 4.9 \\
50\% Clay & 43.7 & 5.4 & 50.6 & 0.3 & 8.7 & 5.4 \\
60\% Clay & 29.4 & 9.6 & 60.7 & 0.3 & 8.4 & 6.4 \\
70\% Clay & 18.8 & 9.6 & 71.1 & 0.5 & 8.3 & 6.9 \\
0.5\% SOM & 93.3 & 0.7 & 5.4 & 0.6 & 9.1 & 2.8 \\
1\% SOM & 92.7 & 0.7 & 5.4 & 1.2 & 8.8 & 3 \\
2\% SOM & 91.7 & 0.7 & 5.4 & 2.2 & 7.8 & 17.1 \\
3\% SOM & 90.9 & 0.7 & 5.4 & 3 & 7.8 & 24.2 \\
4\% SOM & 89.8 & 0.7 & 5.4 & 4.1 & 7.3 & 30 \\
8\% SOM & 85 & 1.7 & 5.4 & 7.9 & 7.1 & 35 \\
16\% SOM & 77.4 & 1.4 & 5.4 & 15.8 & 6.9 & 75.8 \\
32\% SOM & 62 & 0.9 & 5.4 & 31.7 & 6.6 & 121.6 \\
pH 4 & 68.4 & 10.8 & 16.8 & 4 & 4.07 & 6.6
\end{tabular}

a Abbreviations: SOM, soil organic matter; CEC, cation exchange capacity.

\subsection{Preparation of Soils}

A kaolinite clay (Plus White Clay, Charles B. Chrystal Co., Inc., New York, NY 10007), hereafter referred to as clay, was added to sand (Premium play sand, The Quikrete Companies, Atlanta, GA 30329) on a dry weight-to-weight basis to achieve a titration of soil clay content. Soils ranged from $0 \%$ clay to $70 \%$ clay varying by $10 \%$, resulting in eight unique test soils. Organic soil was obtained from the Michigan State University Muck Farm $\left(42.82^{\circ} \mathrm{N}, 84.37^{\circ} \mathrm{W}\right)$ in Laingsburg and is described as a Houghton muck soil (Euic, mesic Typic Haplosaprist) derived from reed sedge plant materials containing $82 \%$ organic matter by mass. The organic soil was passed through a 2-mm sieve to remove large debris prior to mixing and was added to sand on a dry weight-to-weight basis to achieve $0.5,1,2$, $4,8,16$, and $32 \%$ SOM.

A soil of $\mathrm{pH} 4.8$ from a blueberry field consisting of a Pipestone-Kingsville soil (complex, sandy, mixed, mesic Typic Endoaquod) was adjusted to desired $\mathrm{pH}$ values of 4, 5, 6, and 7 using $\mathrm{NaOH}$ (to alkalify) and $\mathrm{H}_{3} \mathrm{PO}_{4}$ (to acidify). As with the organic soil, the base soil was passed through a 2-mm sieve prior to acid or base treatment to remove debris and large particles. Calculated amounts of acid and base were dissolved in $3 \mathrm{~L}$ of de-ionized water and added to $8 \mathrm{~kg}$ of soil to make a soil solution. The soil solution was mixed thoroughly and spread over a large surface area to allow for rapid drying to prevent prolonged anaerobic conditions. The soil was mixed every 3 hours until gravimetric water had evaporated. Soils adjusted with $\mathrm{NaOH}$ were subjected to salinity analysis by determining electrical conductivity using a 1:1 soil to water ratio. The conductivity of soils ranged from 0.4 to $0.7 \mathrm{mmhos} \mathrm{cm}^{-1}$, this was considered to be non-saline for a soil type of loamy sand and able to support normal crop production [22]. Soil $\mathrm{pH}$ was tested after completion of the experiment to determine $\mathrm{pH}$ stability and was found to vary for all soils by 0.02 to 0.16 .

The evaluated weed species consisted of Abutilon theophrasti Medik. (velvetleaf), Amaranthus retroflexus L. (redroot pigweed), Echinochloa crus-galli L. Beauv. (barnyard grass), and Setaria faberi Herrm. (giant foxtail). The A. theophrasti, E. crus-galli, and S. faberi 
populations were collected from maize (Zea mays L.) and soybean fields at the Michigan State University Agronomy Farm $\left(42.71^{\circ} \mathrm{N}, 84.47^{\circ} \mathrm{W}\right)$. The A. retroflexus population was obtained from a commercial source (Azlin Seed Service, Leland, MS 38756, USA). Seeds of each species were planted at a density of 100 seeds per pot to obtain a target population of 50 seedlings, respectively. Soil was added to 7 by 7 by $6.4 \mathrm{~cm}$ pots with the top $1.3 \mathrm{~cm}$ of soil being added after mixing with one of the four weed species. After planting, the soil was brought to field capacity and then either left non-treated or treated with flumioxazin (Valor SX 51 WDG, Valent U.S.A. Corporation, Walnut Creek, CA 94596, USA) at $71 \mathrm{~g}^{\text {ai ha }}{ }^{-1}$ with a track sprayer delivering $187 \mathrm{~L} \mathrm{ha}^{-1}$. Pots were kept in a greenhouse maintained at $25 \pm 5{ }^{\circ} \mathrm{C}$ with a 16-h photoperiod of natural sunlight supplemented with high-pressure sodium lighting to provide $1000 \mu \mathrm{mol} \mathrm{m}{ }^{-2}$ photosynthetic photon flux. The day after application, $0.64 \mathrm{~cm}$ of water was added over the top of all pots to simulate incorporation by rainfall with subsequent moisture provided by sub-irrigation and weekly topical watering of $0.64 \mathrm{~cm}$.

Emerged weeds were counted and removed from pots two weeks after planting using forceps, carefully removing the growing point to minimize soil mixing. Seedling counts were taken for an additional seven weeks after initial removal with $96 \%$ of weed emergence taking place between planting and the first two seedling counts across species. Weed control was calculated using the equation:

$$
y=100-\left(\left(\frac{t}{n}\right) 100\right)
$$

where, $y$ is percent control, $t$ is the number of weeds that emerged in treated soil, and $n$ is the average emergence of weeds in the respective non-treated soil. Weed control was analyzed with SAS 9.1 (Statistical Analysis Systems Institute, Inc., Cary, NC 25712, USA) using PROC MIXED to test for significant interactions between the fixed effects of experiments, weed species, and soil characteristics $(p<0.05)$. The experimental block was considered a random effect. No significant differences were found between experiment runs; therefore, weed control data were pooled across experiment runs. Due to significant species by soil interactions, and the large main effect of soil characteristics, weed control was evaluated separately by soil characteristics with comparisons amongst species. Weed control for species affected by soil differences was fit with trend lines using Sigma Plot software (Systat Software, Inc. version 12.5, San Jose, CA 95131, USA) and was modeled using either linear or inverse first-order, regression. Inverse first-order regression fit is described as:

$$
y=b+\frac{a}{x}
$$

where, $y$ is the weed control achieved at level $x^{-1}$ with asymptote $b$.

\subsection{Flumioxazin Residual Control}

Two separate greenhouse experiments were conducted at Michigan State University to investigate the effect of SOM and soil $\mathrm{pH}$ on flumioxazin residual control. The SOM and soil $\mathrm{pH}$ studies were arranged in a randomized complete block with a factorial arrangement of treatments and were repeated in time. Experimental factors included: five soils, four weed species, two herbicide treatments (treated with flumioxazin or non-treated), and five planting times $(0,2,4,6$, and 8 weeks after treatment [WAT]) with three replications. The soils utilized for the study were either field soils collected based on desired properties with no prior history of flumioxazin application or soils that were artificially adjusted to provide a range of values for the characteristics to be investigated. Soils collected from the field were taken from uniform areas in respective locations from the top $13 \mathrm{~cm}$ of soil. The adjusted soils will hereafter be referred to as "lab soils". Soil particle size distribution, $\mathrm{pH}$, cation exchange capacity, and SOM content were determined for each soil used (Table 1). Field soils were investigated to determine if results from the lab soils were representative of expected field results. 


\subsection{Organic Matter Soils}

Organic soil was obtained from the Michigan State University Muck Farm $\left(42.82^{\circ} \mathrm{N}\right.$, $84.37^{\circ} \mathrm{W}$ ) and is described as Houghton muck soil (Euic, mesic Typic Haplosaprists) derived from reed sedge plant materials containing $82 \%$ organic matter by mass. The organic soil was passed through a 2-mm sieve to remove large debris prior to mixing and was added to sand on a dry weight-to-weight basis to achieve 0,1 , and 3\% SOM. Field soils of 3\% SOM (Capac loam, fine-loamy, mixed, mesic Aeric Ochraqualfs) and the unadjusted organic soils were also included for comparison.

\section{5. $\mathrm{pH}$ Soils}

A Capac loam (fine-loamy, mixed, mesic Aeric Ochraqualf) with a pH 6 was collected from a field in a corn-soybean rotation and was adjusted to the desired $\mathrm{pH}$ levels of 5 and 7 using $\mathrm{H}_{3} \mathrm{PO}_{4}$ and $\mathrm{Ca}(\mathrm{OH})_{2}$, respectively. As with the organic soil, the base soil was passed through a 2-mm sieve prior to acid or base treatment to remove debris and large particles. To adjust the $\mathrm{pH}$, calculated amounts of acid and base were dissolved in $3 \mathrm{~L}$ of de-ionized water and added to $8 \mathrm{~kg}$ of soil to create a soil solution. Once in a solution, soil was mixed thoroughly and spread over a large surface area to allow for rapid drying to prevent prolonged anaerobic conditions. The soil was mixed every $3 \mathrm{~h}$ until gravimetric water had evaporated. Soils of Capac loam (different from the $\mathrm{pH}$ experiment soil) with a pH 5 and a Spinks loam (mixed, mesic Psammentic Hapludalf) pH 7 were collected from fields in corn-wheat-soybean rotations currently planted with wheat under-seeded with red clover (Trifolium pratense) were also included for comparison.

Tested weed species were the same as the initial control experiment apart from excluding E. crus-galli due to poor germination and including Chenopodium album L. (common lamsbsquarters) to include another small-seeded broadleaf species. Seeds of each species were planted at 150 seeds per pot, respectively, except for $A$. theophrasti, which was planted at 65 seeds per pot to obtain a target population of 50 seedlings. Lab soil and field soil were added to 7.0 by 7.0 by $6.4 \mathrm{~cm}$ pots brought to field capacity and were either non-treated or treated with flumioxazin at $71 \mathrm{~g}$ ai ha ${ }^{-1}$ with a track sprayer delivering $187 \mathrm{~L} \mathrm{ha}^{-1}$. Once treated, pots were placed in a greenhouse maintained at $25 \pm 5^{\circ} \mathrm{C}$ with a 16 -hour photoperiod of natural sunlight supplemented with high-pressure sodium lighting to provide $1000 \mu \mathrm{mol} \mathrm{m}{ }^{-2}$ photosynthetic photon flux. Weed seeds were planted by scattering one of the four species onto the soil surface then incorporating them with forceps to a depth of 0.5 to $1 \mathrm{~cm}$ at $0,2,4,6$, and 8 WAT. At each timing, weeds were planted into treated and non-treated soil to evaluate residual control of flumioxazin and to assure that emergence of weeds in treated soils was due solely to chemical control and not changes in the soil. The day after application, $0.64 \mathrm{~cm}$ of water was added over the top of all pots to simulate incorporation by rainfall with subsequent moisture provided by sub-irrigation and weekly topical watering of $0.64 \mathrm{~cm}$.

\section{Data Collection and Analysis}

Emerged weeds were counted and removed from pots weekly using forceps carefully removing the growing point to minimize soil mixing. Seedling counts were taken for three weeks after each respective planting with $94 \%$ of weed emergence taking place between planting and the first count at one week after planting. Weed control was calculated using Equation (1).

Weed control was analyzed with SAS 9.1 (Statistical Analysis Systems Institute, Inc., Cary, NC 25712, USA) using PROC MIXED to test for significant interactions between the fixed effects of runs, weed species, time after application, and soil effect on weed control $(p<0.05)$. Block was considered a random effect. No significant differences were found between experiment runs; therefore, weed control data were pooled across experiment runs. Due to significant species by soil by time interactions, and the large main effect of soil characteristic, weed control was evaluated separately by soil characteristic with comparisons among species. Weed control for species as affected by soil differences was fit 
with trend lines using Sigma Plot software (Systat Software, Inc. version 12.5, San Jose, CA 95131, USA) and was modeled using either linear or logistic regression. Logistic regression fit to data is described as:

$$
y=a /\left(1+(x / b)^{\wedge} c\right)
$$

where, $y$ is weed control achieved at level $x$ with an upper asymptote of $a$ (with a forced upper limit of 100) and slope of $c$ with the point of inflection $b$ [28]. The time that elapsed in weeks until a $50 \%$ reduction in weed control was observed $\left(\mathrm{I}_{50}\right)$ and was calculated for each soil and weed species using the respective regression equation to compare weed control between species and soils.

\section{Results and Discussion}

\subsection{Flumioxazin Initial Control}

Flumioxazin control varied by soil characteristics and weed species (Table 2). Control of weeds with flumioxazin as affected by SOM was best modeled by linear regression, while the effect of $\mathrm{pH}$ on control was best modeled by inverse first-order regression with the coefficient of determination values ranging from 0.31 to 0.78 .

Table 2. Seedling count of weed species averaged by soil and regression equation used to model weed control for clay, SOM and $\mathrm{pH}$ soils ${ }^{\mathrm{a}}$.

\begin{tabular}{ccccc}
\hline Soil & Species & Emergence & Model $^{\mathbf{b}}$ & $\mathbf{r}^{\mathbf{2}}$ \\
\hline Clay & & & & \\
& ABUTH & 26 & $\mathrm{NS}$ & $\mathrm{NS}$ \\
& AMARE & 29 & $\mathrm{NS}$ & $\mathrm{NS}$ \\
& ECHCG & 88 & $\mathrm{NS}$ & $\mathrm{NS}$ \\
$\mathrm{SOM}$ & SETFA & 18 & $\mathrm{NS}$ & 0.31 \\
& & & $y=94.64-0.69 b$ & $\mathrm{NS}$ \\
& ABUTH & 41 & $\mathrm{NS}$ & 0.66 \\
& AMARE & 70 & $y=95.69-1.06 b$ & 0.48 \\
$\mathrm{pH}$ & ECHCG & 86 & $y=92.03-0.89 b$ & 0.78 \\
& SETFA & 28 & $y=139.24(256.33 / b)$ & $\mathrm{NS}$ \\
& ABUTH & 32 & $\mathrm{NS}$ & $\mathrm{NS}$ \\
& AMARE & 22 & $\mathrm{NS}$ & 0.53 \\
\hline
\end{tabular}

a Abbreviations: SOM, organic matter; ABUTH, Abutilon theophrasti; AMARE, Amaranthus retroflexus; ECHCG, Echinochloa crus-galli; SETFA, Setaria faberi; NS, not significant; ${ }^{\mathrm{b}}$ Regression models fit to data include linear $(y=a+b x)$ and inverse first-order regression $(y=b+a / x)$.

Clay content did not affect flumioxazin control of any of the tested species (Figure 1). Flumioxazin has been shown to form relatively weak associations with clay particles. Weak adsorption of flumioxazin by clay particles has been suggested to be due to an electronegative region on the molecule causing repulsion with negative surfaces like clay particles [1] Therefore, due to low adsorption by clay particles, flumioxazin availability is dependent on soil water content [1]. Since soils were maintained at or near field capacity through the duration of the experiment, $100 \%$ weed control was observed for all tested species.

Soil organic content effect on weed control varied by species, with control decreasing as SOM content increased (Figure 2). Sebastian et al. [18] found a similar response of decreased flumioxazin control on Kochia scoparia L. (kochia) as the SOM increased in similar laboratory experiments. A similar negative correlation of flumioxazin availability and SOM was reported by Schutte et al. [29]. Increasing SOM content reduced control of all species except $A$. retroflexus and was significantly different due to high sensitivity to flumioxazin $(p<0.05)$. The decrease in weed control as SOM increased, as determined from the slope of the regression equations, were 1.06, 0.89, and 0.69 for E. crus-galli, S. faberi, and A. theophrasti, respectively. Control of E. crus-galli, S. faberi, and A. theophrasti at 3\% SOM, common to soils in Michigan, could be greater than $85 \%$ for all tested species. Conversely, $A$. retroflexus 
was completely controlled across the SOM contents tested. Differences in control of weed species due to SOM content are likely due to increased adsorption by hydrophobic bonding to SOM, decreasing herbicide concentration in solution available for control $[3,21,22]$. The relative control of weed species by flumioxazin across various SOM contents was as follows, from greatest to least control: A. retroflexus, A. theophrasti, S. faberi, E. crus-galli, similar to reports by others; however, the level of control observed at various SOM contents differed from the presented experiment. Wilson et al. [10] found that flumioxazin applied at $53 \mathrm{~g}$ ai ha ${ }^{-1}$ (lower than the flumioxazin rate $\left[71 \mathrm{~g}\right.$ ai ha $\left.{ }^{-1}\right]$ used in this experiment) to SOM content of $0.8 \%$ provided 90 and $56 \%$ control of $A$. retroflexus and E. crus-galli, respectively, 4 WAT in the field. At $0.8 \%$ SOM, the observed control of A. retroflexus and E. crus-galli was 100 and 95\%, respectively, which could be due to the higher flumioxazin rate used in the experiment. Niekamp and Johnson [9] observed that flumioxazin at ate of $71 \mathrm{~g}^{\text {ai ha }} \mathrm{ha}^{-1}$ applied to soil containing 2.5\% SOM provided 82 and $63 \%$ control of $A$. theophrasti and S. faberi, respectively, 7 WAT in the field. At 2.5\% SOM, the observed control of $A$. theophrasti and S. faberi was 93 and 90\%, respectively. Lastly, Taylor-Lovell et al. [19] found 99\% control of $A$. theophrasti at $105 \mathrm{~g}$ ai ha ${ }^{-1}$ of flumioxazin, while only 74 to $78 \%$ control of $S$. faberi when SOM was $5.6 \%$ in the field. At 5.6\% SOM, the observed control of $A$. theophrasti and $S$. faberi was 91 and $87 \%$, respectively. The observed control reported in field studies was generally lower than what was observed here, suggesting that differences in control could be due to the continual emergence of weeds, whereas weed emergence was finite in this experiment during a short period of time. Differences between studies also could be due to environmental effects, including rain and soil moisture which have a large impact on flumioxazin control $[1,18]$.

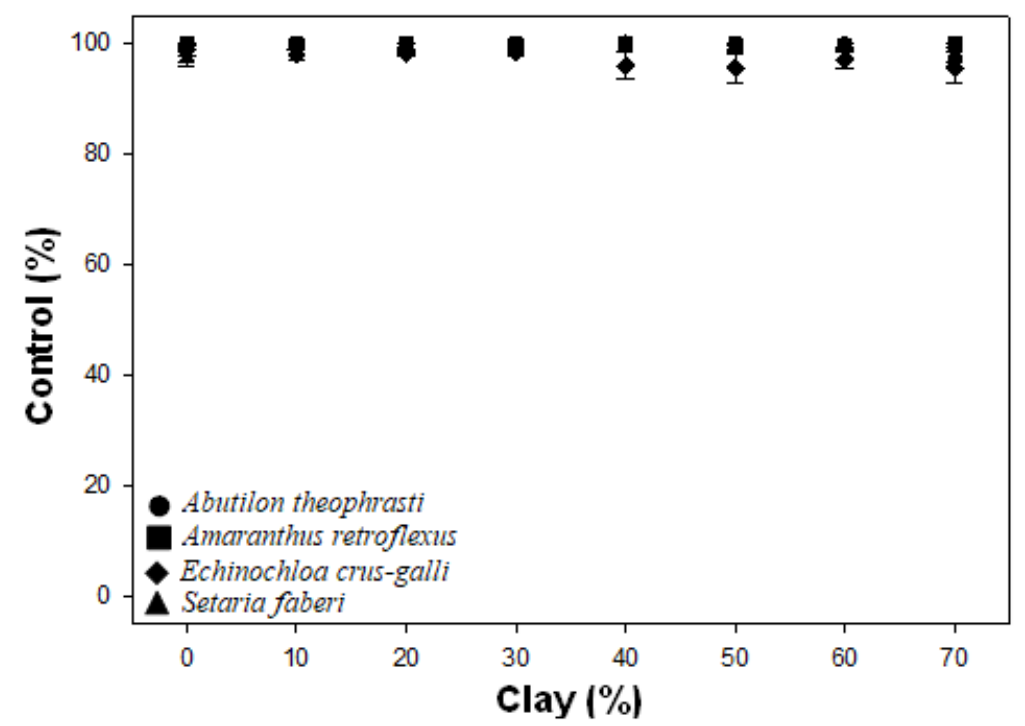

Figure 1. Control of flumioxazin on select weed species as affected by clay content. Control of flumioxazin was not affected by clay content across weed species $(p<0.05)$. The vertical bars represent the standard error of means.

The effect of soil $\mathrm{pH}$ on weed control varied by species (Figure 3). The control of S. faberi and A. theophrasti was significantly decreased when soil $\mathrm{pH}$ was below 6 , with control reduced to 76 and $75 \%$, respectively, at a soil pH of 4 . Ferreira et al. [25] demonstrated at a $\mathrm{pH}$ of 5.5 or lower, SOM increased in hydrophobicity which could potentially cause increased herbicide adsorption, which could explain the reduction in control of $S$. faberi and $A$. theophrasti. In contrast, the control of A. retroflexus and E. crus-galli was not affected by soil $\mathrm{pH}$. The control of $A$. retroflexus was $100 \%$ at $\mathrm{pH}$ values lower than 6 because the species is highly susceptible to flumioxazin. Echinochloa crus-galli was controlled at $\mathrm{pH}$ values less than 6 , regardless of observations of relative tolerance to flumioxazin at higher SOM. 


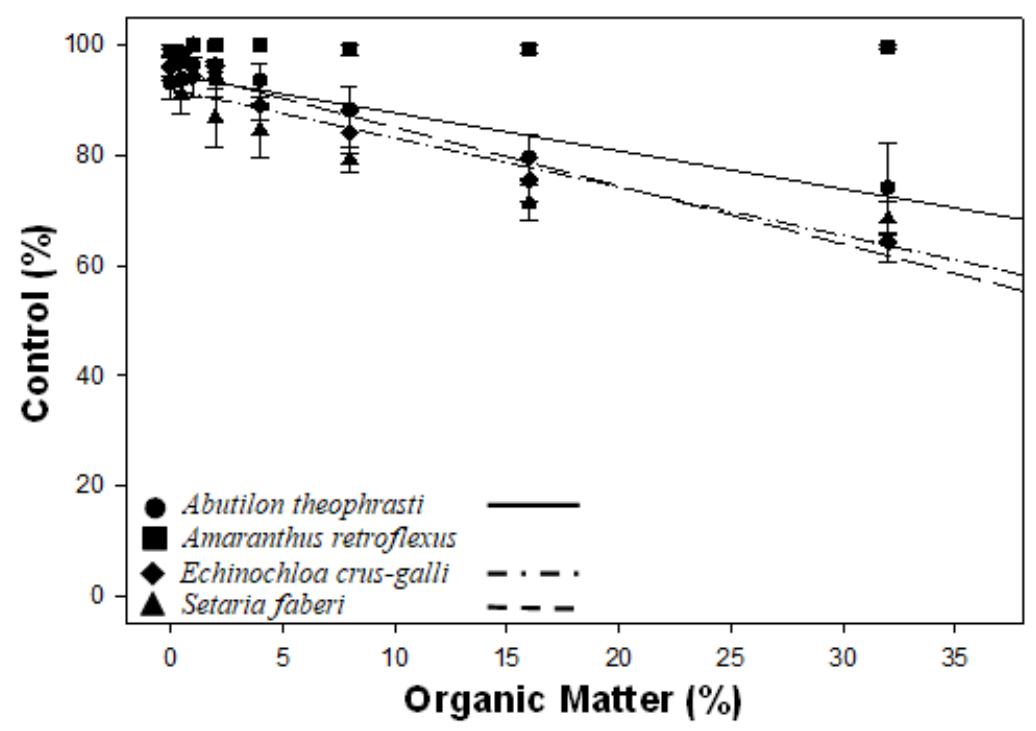

Figure 2. Control of flumioxazin on select weed species as affected by soil organic matter content. Fitted lines are calculated by the linear regression equation $(y=a+b x)$ for Abutilon theophrasti, Echinochloa crus-galli, and Setaria faberi $(p<0.05)$. Flumioxazin control on A. theophrasti, E. crus-galli, and $S$. faberi decreased with increasing soil organic matter content. Flumioxazin control on Amaranth retroflexus did not change across soil organic matter content $(p>0.05)$. The vertical bars represent the standard error of means.

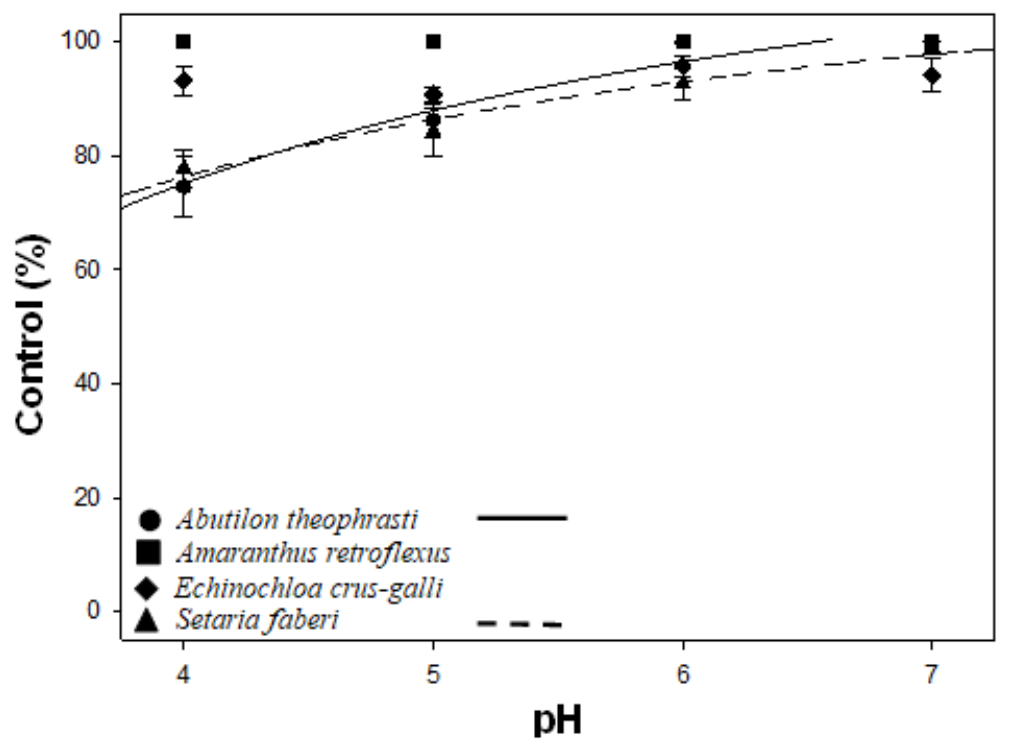

Figure 3. Control of flumioxazin on select weed species as affected by soil $\mathrm{pH}$. Fitted lines are calculated by the inverse first-order regression equation $(y=b+a / x)$ for Abutilon theophrasti and Setaria faberi $(p<0.05)$. Flumioxazin control on $A$. theophrasti and $S$. faberi increased with increasing soil $\mathrm{pH}$. Flumioxazin control on Amaranth retroflexus and Echinochloa crus-galli did not change across soil $\mathrm{pH}(p>0.05)$. The vertical bars represent the standard error of means.

Control of weed species in field studies was generally lower than that observed in the greenhouse experiment. Taylor-Lovell et al. [19] found at $105 \mathrm{~g}$ ai ha ${ }^{-1}$ of flumioxazin and a soil pH of 6 , control of $A$. theophrasti was $99 \%$, similar to the experiment findings of $97 \%$ control with $71 \mathrm{~g}$ ai ha ${ }^{-1}$ of flumioxazin. Taylor-Lovell et al. [19] observed $74-78 \%$ control of S. faberi, while here, 93\% control was observed. Niekamp and Johnson [9] observed that flumioxazin added to soil with a $\mathrm{pH}$ of 6.5 at a rate of $71 \mathrm{~g}$ ai ha ${ }^{-1}$, provided 82 and $63 \%$ control of $A$. theophrasti and $S$. faberi, respectively, 7 WAT. At a $\mathrm{pH}$ of 6.5 , the observed 
control of $A$. theophrasti and S. faberi was $100 \%$ and $96 \%$, respectively, with the same rate of flumioxazin.

\subsection{Flumioxazin Residual Control}

Weed control with flumioxazin varied by soil type and generally decreased over time (Table 3). Residual weed control was best modeled as a logistic response (24 of 40 models) with 4 models sufficiently explained by linear regression and 12 with no significant regression model (Tables 4 and 5). Models that were significant ranged in coefficient of determination values from 0.72 to 0.98 but in most cases were 0.9 or higher.

Table 3. Properties of the tested lab and field soils to evaluate the effect of soil organic matter and $\mathrm{pH}$ on flumioxazin residual control on Abutilon theophrasti, Amaranthus retroflexus, Chenopodium album, and Setaria faberi ${ }^{\text {a. }}$

\begin{tabular}{ccccccc}
\hline Soil & Sand & Silt & Clay & pH & SOM & CEC \\
\hline Lab Soil pH 5 & 50.4 & 31 & 16.8 & 5.1 & 2.8 & 21 \\
Field Soil pH 5 & 49.8 & 36.8 & 16.8 & 4.9 & 2.3 & 6.6 \\
Field Soil pH 6 & 37.7 & 33.0 & 23.5 & 6 & 3.2 & 19.6 \\
Lab Soil pH 7 & 48.2 & 29.4 & 20.8 & 7 & 3 & 19.7 \\
Field Soil pH 7 & 40 & 29.6 & 27.8 & 7.1 & 2.6 & 12 \\
Lab Soil 0\% SOM & 97.7 & 0.1 & 2.1 & 10 & 0.1 & 0.6 \\
Lab Soil 1\% SOM & 92.7 & 0.7 & 5.4 & 8 & 1.2 & 3 \\
Lab Soil 3\% SOM & 90.9 & 0.7 & 5.4 & 7.6 & 3 & 24.2 \\
Field Soil 3\% SOM & 37.7 & 33 & 23.5 & 6 & 3.2 & 19.6 \\
Organic Soil (Muck) & 7.3 & 9.2 & 1.8 & 6.4 & 81.7 & 142.3 \\
\hline
\end{tabular}

a Abbreviations: SOM, soil organic matter; CEC, cation exchange capacity.

Table 4. Seedling emergence of various weed species averaged over time, $\mathrm{I}_{50}$, and regression equation used to model weed control for organic matter soils ${ }^{\text {a }}$.

\begin{tabular}{|c|c|c|c|c|c|}
\hline 9 & Species & Emer & $I_{50}$ & Model b & $r^{2}$ \\
\hline \multicolumn{6}{|c|}{ LS 0\% SOM } \\
\hline & ABUTH & 36.7 & 5.7 & $y=100 / 1+(x / 5.67)^{9.85}$ & 0.98 \\
\hline & AMARE & 39.7 & NS & NS & NS \\
\hline & CHEAL & 33.5 & NS & NS & NS \\
\hline & SETFA & 41.6 & 6.3 & $y=96.48 / 1+(x / 6.29)^{10.36}$ & 0.98 \\
\hline \multicolumn{6}{|c|}{ LS 1\% SOM } \\
\hline & ABUTH & 37.5 & 5.4 & $y=96.86 / 1+(x / 5.51)^{4.29}$ & 0.95 \\
\hline & AMARE & 38.9 & NS & NS & NS \\
\hline & CHEAL & 35.5 & NS & NS & NS \\
\hline & SETFA & 40.4 & 4.6 & $y=97.13-10.22 x$ & 0.90 \\
\hline \multicolumn{6}{|c|}{ LS 3\% SOM } \\
\hline & ABUTH & 38.9 & 4.4 & $y=93.63-10 x$ & 0.97 \\
\hline & AMARE & 38.3 & 11.6 & $y=100 / 1+(x / 11.57)^{3.63}$ & 0.72 \\
\hline & CHEAL & 35.5 & 13 & $y=100 / 1+(x / 13.04)^{2.88}$ & 0.92 \\
\hline & SETFA & 40.6 & 3.5 & $y=90.7-11.65 x$ & \\
\hline \multicolumn{6}{|c|}{ FS 3\% SOM } \\
\hline & ABUTH & 34.5 & 2.9 & $y=97.76 / 1+(x / 2.92)^{1.82}$ & 0.81 \\
\hline & AMARE & 32.5 & NS & NS & NS \\
\hline & CHEAL & 32.6 & NS & NS & NS \\
\hline & SETFA & 38.5 & 2.8 & $y=92.1 / 1+(x / 3.03)^{2.4}$ & 0.94 \\
\hline \multicolumn{6}{|c|}{ Organic Soil } \\
\hline & ABUTH & 35 & 1.9 & $y=77.42 / 1+(x / 2.44)^{2.6}$ & 0.95 \\
\hline & AMARE & 38.9 & 6.9 & $y=100 / 1+(x / 6.92)^{9.28}$ & 0.97 \\
\hline & CHEAL & 34.8 & 7.3 & $y=100 / 1+(x / 7.27)^{7.29}$ & 0.98 \\
\hline & SETFA & 37.5 & 1.7 & $y=80.09 / 1+(x / 1.99)^{3.12}$ & 0.93 \\
\hline
\end{tabular}

a Abbreviations: Emer, emergence; SOM, soil organic matter; FS, field soil; LS, lab soil; ABUTH, Abutilon theophrasti; AMARE, Amaranthus retroflexus; CHEAL, Chenopodium album; SETFA, Setaria faberi; $\mathrm{I}_{50}$, weeks until a $50 \%$ reduction in control; NS, not significant; ${ }^{b}$ models fit to data include linear $(y=a+b x)$ and logistic regression $\left(y=\frac{a}{1+\left(\frac{x}{b}\right)^{c}}\right)$. 
Table 5. Seedling emergence of various weed species averaged over time, $\mathrm{I}_{50}$, and regression equation used to model weed control for soil $\mathrm{pHs}^{\mathrm{a}}$.

\begin{tabular}{|c|c|c|c|c|c|}
\hline Scheme 50. & Species & Emer & $\mathbf{I}_{50}$ & Model $^{\mathbf{b}}$ & $r^{2}$ \\
\hline \multicolumn{6}{|l|}{ LS pH 5} \\
\hline & ABUTH & 34.9 & 4.49 & $y=94.37 / 1+(x / 4.53)^{14.76}$ & 0.95 \\
\hline & AMARE & 33.1 & NS & NS & NS \\
\hline & CHEAL & 32.6 & NS & NS & NS \\
\hline & SETFA & 41.8 & 5.60 & $y=93.55 / 1+(x / 5.74)^{5.58}$ & 0.9 \\
\hline \multicolumn{6}{|l|}{ FS pH 5} \\
\hline & ABUTH & 34.1 & 4.49 & $y=93.98 / 1+(x / 4.53)^{14.63}$ & 0.98 \\
\hline & AMARE & 34.2 & NS & NS & NS \\
\hline & CHEAL & 32 & NS & NS & NS \\
\hline & SETFA & 39 & 5.03 & $y=95.68 / 1+(x / 5.11)^{5.55}$ & 0.96 \\
\hline \multicolumn{6}{|l|}{ FS pH 6} \\
\hline & ABUTH & 34.5 & 2.85 & $y=97.76 / 1+(x / 2.92)^{1.82}$ & 0.81 \\
\hline & AMARE & 32.5 & NS & NS & NS \\
\hline & CHEAL & 32.6 & NS & NS & NS \\
\hline & SETFA & 38.5 & 2.82 & $y=92.1 / 1+(x / 3.03)^{2.4}$ & 0.94 \\
\hline \multicolumn{6}{|l|}{ LS pH 7} \\
\hline & ABUTH & 35.8 & 3.25 & $y=97.67 / 1+(x / 3.27)^{9.26}$ & 0.97 \\
\hline & AMARE & 34 & 5.86 & $y=100 / 1+(x / 5.86)^{5.94}$ & 0.95 \\
\hline & CHEAL & 34.3 & 5.93 & $y=100 / 1+(x / 5.93)^{6.69}$ & 0.97 \\
\hline & SETFA & 42.9 & 3.83 & $y=90.63-10.61 x$ & 0.96 \\
\hline \multicolumn{5}{|r|}{ 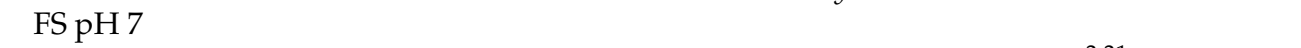 } & 0.98 \\
\hline & AMARE & 32 & 5.64 & $y=100 / 1+(x / 5.64)^{5.71}$ & 0.88 \\
\hline & CHEAL & 31.8 & 5.75 & $y=100 / 1+(x / 5.75)^{5.24}$ & 0.87 \\
\hline & SETFA & 38 & 2.37 & $y=92.98 / 1+(x / 2.62)^{1.53}$ & 0.91 \\
\hline
\end{tabular}

a Abbreviations: Emer, emergence; FS, field soil; LS, lab soil; ABUTH, Abutilon theophrasti; AMARE, Amaranthus retroflexus; CHEAL, Chenopodium album; SETFA, Setaria faberi; $\mathrm{I}_{50}$, weeks until a $50 \%$ reduction in control; NS, not significant; ${ }^{\mathrm{b}}$ models fit to data include linear $(y=a+b x)$ and logistic regression $\left(y=\frac{a}{1+\left(\frac{x}{b}\right)^{c}}\right)$.

\subsection{Organic Soils}

Organic matter content significantly influenced flumioxazin residual control (Figure 4). Weed control at 0 WAT ranged from 77 to $100 \%$, with $\mathrm{I}_{50}$ values ranging from 1.7 to 13 (Table 4). Lab soil with $0 \%$ SOM (100\% sand material) had relatively no effect on weed control, and not until 4 WAT was control reduced for S. faberi and A. theophrasti (Figure 3). Lab soil with $1 \%$ SOM resulted in decreased control of $A$. theophrasti after application, and by 2 WAT, control was reduced by $23 \%$. Control of $S$. faberi was affected by SOM content, with reduced control at 2 WAT and 1\% SOM compared to 4 WAT for $0 \%$ SOM. Control of C. album and A. retroflexus was not reduced during the duration of the experiment at $1 \%$ SOM lab soil; however, control was reduced when SOM was 3\%, and seeds were planted 4 WAT. Residual control of S. faberi and A. theophrasti was greater at $1 \%$ SOM than at $3 \%$ SOM and was also greater in the field soil than the lab soil. The control of C. album and A. retroflexus in field soil showed no differences; however, reduced control was observed as SOM changed in lab soil (Figure 3).

Digression between results of lab and field soil at 3\% SOM could be due to the type of organic matter in each soil. The SOM in the organic soil used to adjust the lab soil could have a greater affinity for flumioxazin (more hydrophobic) than the SOM found in the field soil [8,30-32]. Differences in weed control in the two soils could also be due to the microbial populations associated with the soil, with populations in the lab soils derived from the organic soil more apt to metabolize flumioxazin [33,34] or cause a synergistic control of weeds [35]. Lastly, control was greatly affected by the organic soil with $\mathrm{I}_{50}$ values of 7.3, 1.7, 6.9, and 1.9 for C. album, S. faberi, A. retroflexus, and A. theophrasti, respectively (Table 4). 
Weed control at 0 WAT for the organic soil was 80 and 77\% for S. faberi and A. theophrasti, respectively, which was the lowest initial control observed for either species (Figure 4).
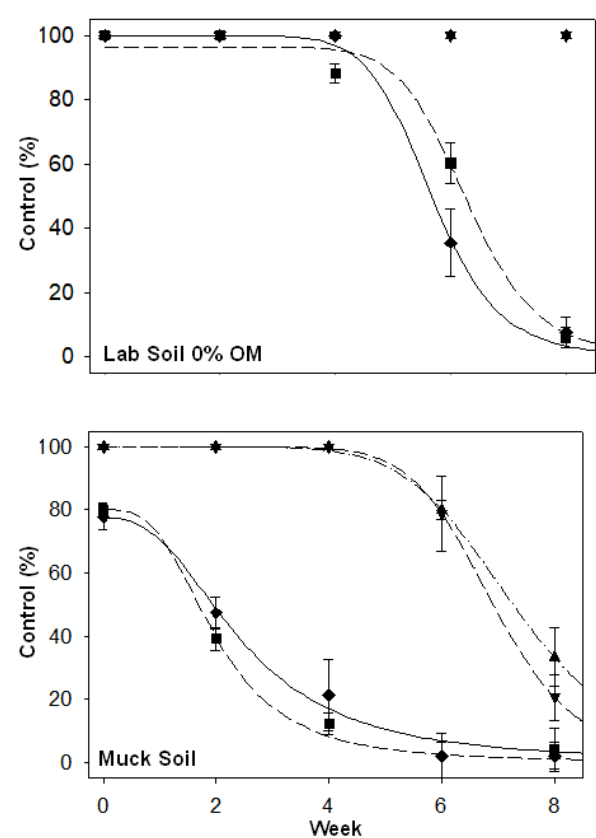
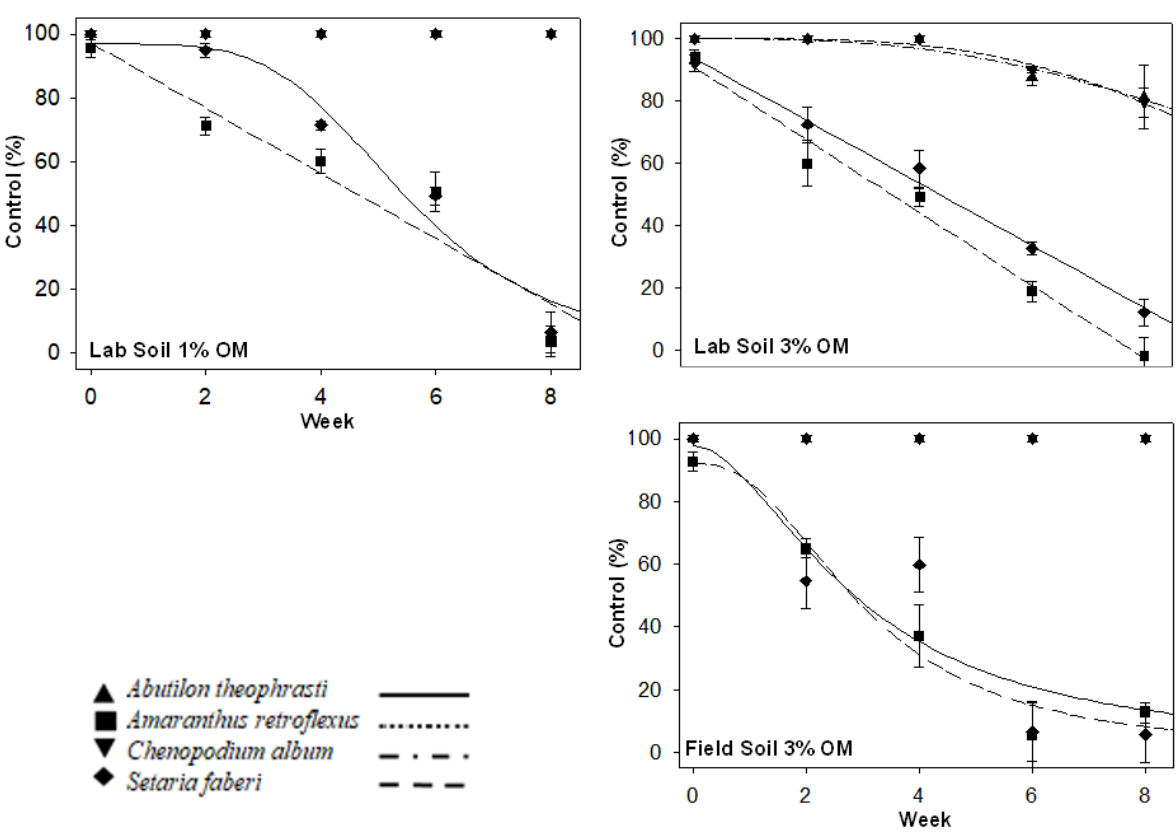

Figure 4. Weed control of Abutilon theophrasti $(\mathbf{\Delta})$, Amaranthus retroflexus $(\mathbf{\square})$, Chenopodium album $(\boldsymbol{\nabla})$, and Setaria faberi $(\boldsymbol{\vee})$ with flumioxazin as affected by percent soil organic matter over time for lab and field soils. Fitted lines for expected control are calculated by linear $(y=a+b x)$ or logistic regression $\left(y=a /\left(1+(x / b)^{\wedge} c\right)\right)$ for Abutilon theophrasti, Amaranthus retroflexus, Chenopodium album, and Setaria faberi. Error bars represent the standard deviation of the mean.

Observed weed control generally decreased as SOM content increased. Control of weed species in response to SOM was similar for the large seeded-broadleaf and grass weed species (A. theophrasti and S. faberi) and the small-seeded broadleaves (A. retroflexus and C. album). However, control of $A$. theophrasti tended to be slightly higher than $S$. faberi control except for at $1 \%$ SOM lab soil, where the $\mathrm{I}_{50}$ value for $S$. faberi was 0.58 greater than A. theophrasti.

\subsection{Soil $p H$}

The residual control of flumioxazin varied greatly by soil $\mathrm{pH}$ and species (Figure 4). Initial weed control across all tested species ranged from 91 to $100 \%$, and $\mathrm{I}_{50}$ values ranged from 2.37 to 5.93 (Table 5). In both lab and field soils at $\mathrm{pH} 5$, control of $C$. album and A. retroflexus remained at $100 \%$ for 8 WAT, while S. faberi and A. theophrasti control decreased over time (Figure 5). Control of S. faberi and A. theophrasti at pH 5 in lab and field soil began to decrease at 2 WAT with $\mathrm{I}_{50}$ values of 5.1 and 4.8, respectively. Minimal differences were observed between the lab and field soil at $\mathrm{pH} 5$ for weed control, with the greatest difference observed in $\mathrm{I}_{50}$ values for $S$. faberi being 0.57 . The control of $C$. album and A. retroflexus was $100 \%$ for the duration of the study at a soil $\mathrm{pH}$ of 6 , similar to the control of these species at a soil $\mathrm{pH}$ of 5 . Control of $S$. faberi and A. theophrasti at $\mathrm{pH} 6$ decreased with a 47 and $37 \%$ reduction in $\mathrm{I}_{50}$ values, respectively. Loss in weed control from $\mathrm{pH} 5$ to 6 could be due to an increase in the ability of the microbial metabolism or hydrolysis of the herbicide $[24,32,35,36]$. The control of weed species in $\mathrm{pH} 7 \mathrm{lab}$ and field soils was similar and only differed by $I_{50}$ values being 0.18 to 0.48 lower for all species except $S$. faberi (1.46) in the field soil. The control of A. retroflexus and C. album did not decrease until 4 WAT at $\mathrm{pH} 7$, regardless of being lab or field soil. However, at $\mathrm{pH} 7$ lab and field soil, control of $A$. theophrasti and S. faberi were similar to the control at $\mathrm{pH} 6$. Reduction in control of C. album and A. retroflexus but not S. faberi and A. theophrasti could be due to a slight decrease in herbicide concentration caused by hydrolysis at the higher $\mathrm{pH}$ [37]. This 
putative decrease in herbicide concentration, however, was not enough to cause a control reduction in the large-seeded species (A. theophrasti and S. faberi).
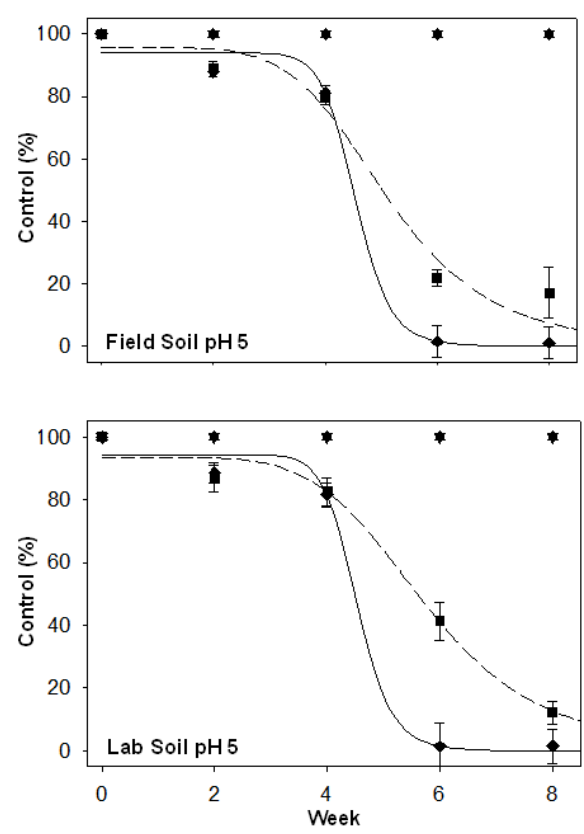
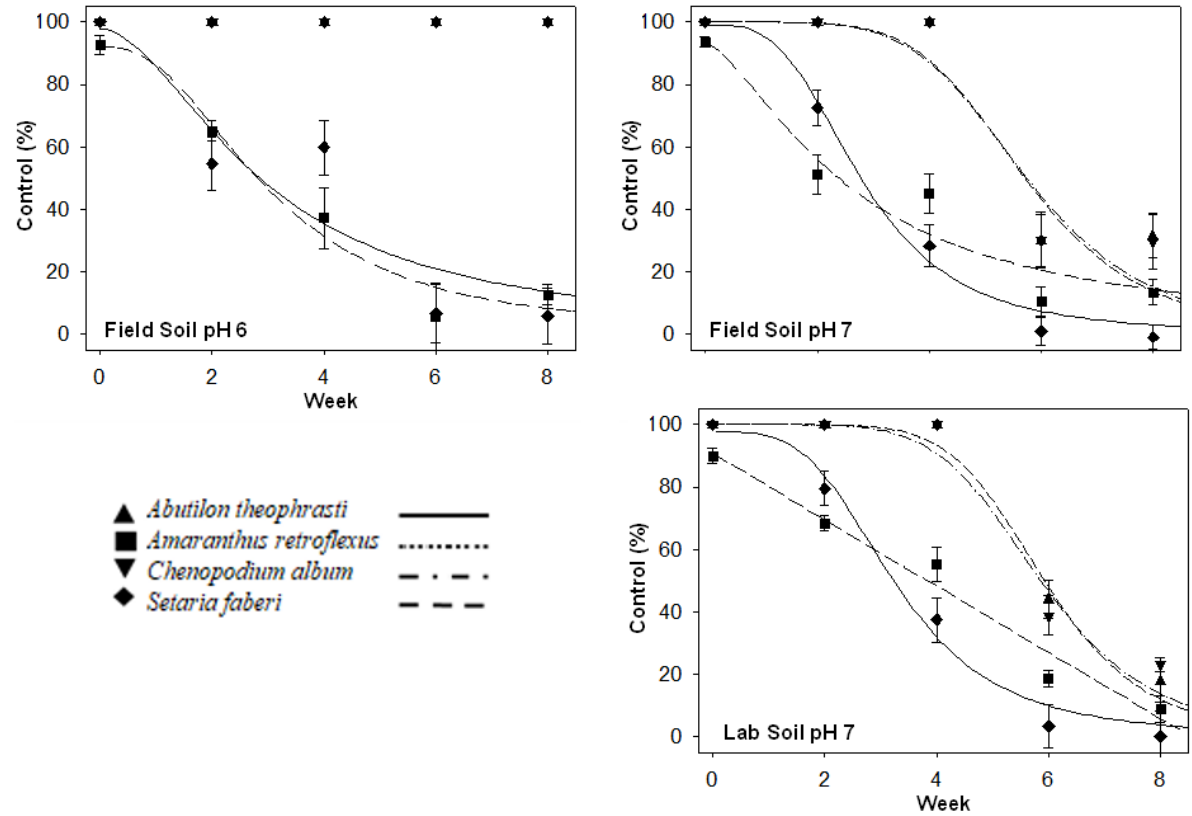

Figure 5. Weed control of Abutilon theophrasti $(\boldsymbol{\Delta})$, Amaranthus retroflexus $(\boldsymbol{\square})$, Chenopodium album $(\boldsymbol{\nabla})$, and Setaria faberi $(\boldsymbol{\vee})$ with flumioxazin as affected by soil $\mathrm{pH}$ over time for lab and field soils. Fitted lines for expected control are calculated by linear $(y=a+b x)$ or logistic regression $\left(y=a /\left(1+(x / b)^{\wedge} c\right)\right)$ for Abutilon theophrasti, Amaranthus retroflexus, Chenopodium album, and Setaria faberi. Error bars represent the standard deviation of the mean.

Control of all species decreased over time as soil pH increased (Figure 5). The reduction in control of C. album and A. retroflexus only occurred at the highest soil $\mathrm{pH}$ tested; however, control of S. faberi and A. theophrasti decreased when $\mathrm{pH}$ was raised from 5 to 6 . When comparing species responses to soil $\mathrm{pH}$, it was observed that similar to SOM soils, C. album and $A$. retroflexus had similar responses while $S$. faberi and $A$. theophrasti responded similarly. The reason for differences between the two pairs of weed species and similarities within the pairs could be attributed to seed size, which has been shown to influence herbicide uptake [38].

\section{Conclusions}

The results indicate that $\mathrm{SOM}$ content and $\mathrm{pH}$ value can adversely impact the initial control effect of flumioxazin on weed species, while clay content does not interfere with flumioxazin control. Additionally, this research shows that increasing SOM and solution $\mathrm{pH}$ decreases flumioxazin residual control. Thus, the results reject the null hypotheses for the effect of SOM content and $\mathrm{pH}$ on flumioxazin control of select weed species; additionally, the results fail to reject the null hypothesis of the effect of clay control in select weed species with flumioxazin.

Understanding the effects of different soil characteristics on the adsorption of flumioxazin will allow for soil and weed species to have specific herbicide recommendations. If the prevalent weed species are small-seeded broadleaves (i.e., A. retroflexus or C. album), a use rate of $71 \mathrm{~g}$ ai ha ${ }^{-1}$ will provide $100 \%$ control regardless of SOM content and soil $\mathrm{pH}$ for approximately six weeks. However, if the prevalent weed species are grasses or large-seeded broadleaves (i.e., A. theophrasti), flumioxazin may need to be tank-mixed with an efficacious herbicide to achieve $>85 \%$ control for a duration longer than two weeks (dependent or independent of SOM). While most crops are grown in soils with $3-5 \%$ OM, there are areas in the world where crops are grown in soils containing low or high $\mathrm{OM}$, as tested in this research. These results provide information regarding flumioxazin control 
on pervasive row crop weeds with ubiquitous and anomalous soil characteristics. Adjusting herbicide recommendations based on soil type, and prevalence of weed species, can potentially reduce herbicide use and/or improve weed control.

Author Contributions: All authors equally contributed to the conceptualization, original draft preparation, and review and editing of this manuscript. All authors have read and agreed to the published version of the manuscript.

Funding: Project funding was provided by Valent.

Institutional Review Board Statement: Not applicable.

Informed Consent Statement: Not applicable.

Data Availability Statement: The data presented in this study are available on request from the corresponding author.

Conflicts of Interest: No conflict of interest have been declared.

\section{References}

1. Ferrell, J.A.; Vencill, W.K.; Xia, K.; Grey, T.L. Sorption and desorption of flumioxazin to soil, clay minerals and ion-exchange resin. Pest Manag. Sci. 2005, 61, 40-46. [CrossRef]

2. Wauchope, D.R.; Yeh, S.; Linders, J.B.; Kloskowski, R.; Tanka, K.; Rubin, B.; Katayama, A.; Kördel, W.; Gerstl, Z.; Lane, M.; et al. Pesticide soil sorption parameters: Theory, measurement, uses, limitations and reliability. Pest Manag. Sci. 2002, 58, $419-445$. [CrossRef]

3. Peter, C.J.; Weber, J.B. Adsorption, mobility, and efficacy of alachlor and metolachlor as influenced by soil properties. Weed Sci. 1985, 33, 874-881. [CrossRef]

4. Walker, A. Activity and Selectivity in the field. In Interactions between Herbicides and the Soil; Hance, R.J., Ed.; Academic Press: New York, NY, USA, 1980; pp. 203-222.

5. Monaco, T.J.; Weller, S.C.; Ashton, F.M. Weed Science Principles and Practices, 4th ed.; John Wiley \& Sons, Inc.: New York, NY, USA, 2002; pp. 127-145.

6. Weber, J.B.; Warren, R.L.; Swain, L.R.; Yelverton, F.H. Physicochemical property effects of three herbicides and three soils on herbicide mobility in field lysimeters. Crop. Prot. 2007, 26, 299-311. [CrossRef]

7. Benoit, P.; Madrigal, I.; Preston, C.M.; Chenu, C.; Barriuso, E. Sorption and desorption of non-ionic herbicides onto particulate organic matter from the surface soils under different land uses. Eur. J. Soil Sci. 2008, 59, 178-189. [CrossRef]

8. Walker, A.; Austin, C.R. Effect of recent cropping history and herbicide use on degradation rates of isoproturon in soils. Weed Res. 2003, 44, 5-11. [CrossRef]

9. Niekamp, J.W.; Johnson, W.G. Weed management with sulfentrazone and flumioxazin in no-tillage soyabean (Glycine max). Crop Prot. 2001, 20, 215-220. [CrossRef]

10. Wilson, D.E.; Nissen, S.J.; Thompson, A. Potato (Solanum tuberosum) variety and weed response to sulfentrazone and flumioxazin. Weed Technol. 2002, 16, 567-574. [CrossRef]

11. Clewis, S.B.; Everman, W.J.; Jordan, D.L.; Wilcut, J.W. Weed management in North Carolina peanuts (Arachis hyogaea) with S-metoalchlor, diclosulam, flumioxazin, and sulfentrazone systems. Weed Technol. 2007, 21, 629-635. [CrossRef]

12. Everman, W.J.; Clewis, S.B.; York, A.C.; Wilcut, J.W. Weed control and yield with flumioxazin, fomesafen, and S-metolachlor systems for glufosinate-resistant cotton residual weed wanagement. Weed Technol. 2009, 23, 391-397. [CrossRef]

13. Hausman, N.E.; Tranel, P.J.; Riechers, D.E.; Maxwell, D.J.; Gonzini, L.C.; Hager, A.G. Responses of an HPPD inhibitor-resistant waterhemp (Amaranthus tuberculatus) population to soil-residual herbicides. Weed Technol. 2013, 27, 704-711. [CrossRef]

14. Westhoven, A.M.; Stachler, J.M.; Loux, M.M.; Johnson, W.G. Management of glyphosate-tolerant common lambsquarters (Chenopodium album) in glyphosate-resistant soybean. Weed Technol. 2008, 22, 628-634. [CrossRef]

15. Grey, T.L.; Wehtje, G.R. Residual herbicide weed control systems in peanut. Weed Technol. 2005, 19, 560-567. [CrossRef]

16. Mahoney, K.J.; Shropshire, C.; Sikkema, P.H. Weed management in conventional-and no-till soybean using flumioxazin/pyroxasulfone. Weed Technol. 2014, 28, 298-306. [CrossRef]

17. Norsworthy, J.K.; McClelland, M.; Griffith, G.M. Conyza canadensis (L.) cronquist response to pre-plant application of residual herbicides in cotton (Gossypium hirsutum L.). Crop Prot. 2009, 28, 62-67. [CrossRef]

18. Sebastian, D.J.; Nissen, S.J.; Westra, P.; Shaner, D.L.; Butters, G. Influence of soil properties and soil moisture on the efficacy of indaziflam and flumioxazin on Kochia scoparia L. Pest Manag. Sci. 2016, 73, 444-451. [CrossRef]

19. Taylor-Lovell, S.; Wax, L.M.; Bollero, G. Preemergence flumioxazin and pendimethalin and postemergence herbicide systems for soybean (Glycine max). Weed Technol. 2002, 16, 502-511. [CrossRef]

20. Calvet, R. Adsorption-desorption phenomena. In Interactions between Herbicides and the Soil; Hance, R.J., Ed.; Academic Press: New York, NY, USA, 1980; pp. 1-30. 
21. Koskinen, W.C.; Moorman, T.B. Effect of soil properties and processes on herbicide performance. In Weeds of Cotton Characterization and Control; McWhorter, C.G., Abernathy, J.R., Eds.; The Cotton Foundation: Memphis, TN, USA, 1992; pp. $365-402$.

22. Kah, M.; Brown, C.D. Absorption of ionisable pesticides in soils. Rev. Environ. Contam Toxicol. 2006, 188, $149-217$.

23. Sposito, G.; Skipper, N.T.; Sutton, R.; Park, S.; Soper, A.K.; Greathouse, J.A. Surface geochemistry of clay minerals. Proc. Natl. Acad. Sci. USA 1999, 96, 3358-3364. [CrossRef]

24. Ferreira, J.A.; Nascimento, O.R.; Martin-Neto, L. Hydrophobic interactions between spin-label 5-sasl and humic acid as revealed by ESR spectroscopy. Environ. Sci. Technol. 2001, 35, 761-765. [CrossRef]

25. Alister, C.S.; Gómez, R.P.; Kogan, M. Dissipation and movement of flumioxazin in soil at four field sites in Chile. Pest Manag. Sci. 2008, 64, 579-583. [CrossRef]

26. Boyd, N.S.; Sharpe, S.M.; Ramdas, K. Flumioxazin soil persistence under plastic mulch and effects of pretransplant applications on strawberry. Weed Technol 2021, 35, 319-323. [CrossRef]

27. Price, A.J.; Koger, C.H.; Wilcut, J.W.; Miller, D.; Santen, E.V. Efficacy of residual and non-residual herbicides used in cotton production systems when applied with glyphosate, glufosinate, or MSMA. Weed Technol. 2008, 22, 459-466. [CrossRef]

28. Seefeldt, S.S.; Jensen, J.E.; Fuerst, E.P. Log-logistic analysis of herbicide dose-response relationships. Weed Technol. 1995, 9, $218-227$. [CrossRef]

29. Schutte, B.J.; Lehnhoff, E.A.; Beck, L.L. Evaluation of POST-directed applications of flumioxazin in New Mexico chile pepper. Weed Technol. 2018, 33, 135-141. [CrossRef]

30. Mueller-Warrant, G.W. Duration of control from preemergence herbicides for use in nonburned grass seed crops. Weed Technol. 1999, 13, 439-449. [CrossRef]

31. Torrents, A.; Jayasundera, S. The sorption of non-ionic pesticides onto clay and the influence of natural organic carbon. Chemosphere 1997, 7, 1549-1565. [CrossRef]

32. Ferrell, J.A.; Vencill, W.K. Flumioxazin soil persistence and mineralization in laboratory experiments. J. Agric. Food Chem. 2003, 51, 4719-4721. [CrossRef]

33. André, C.L.; Rahe, J.E. Herbicide interactions with fungal root pathogens, with special reference to glyphosate. Annu. Rev. Phytopathol. 1992, 30, 579-602.

34. Anderson, T.H.; Domsch, K.H. The metabolic quotient for $\mathrm{CO}_{2}\left(\mathrm{qCO}_{2}\right)$ as a specific activity parameter to assess the effects of environmental conditions, such as $\mathrm{pH}$, on the microbial biomass of forest soils. Soil Biol. Biochem. 1992, 25, 393-395. [CrossRef]

35. Corbin, F.T.; Upchurch, R.P. Influence of $\mathrm{pH}$ on detoxication of herbicides in soil. Weeds 1967, 15, 370-377. [CrossRef]

36. Torstensson, L. Role of microorganisms in decomposition. In Interactions between Herbicides and the Soil; Hance, R.J., Ed.; Academic Press: New York, NY, USA, 1980; pp. 159-178.

37. Kwon, J.; Armbrust, K.L.; Grey, T.L. Hydrolysis and photolysis of flumioxazin in aqueous buffer solutions. Pest Manag. Sci. 2004, 60, 939-943. [CrossRef] [PubMed]

38. Scott, H.D.; Phillips, R.E. Diffusion of herbicides to seed. Weed Sci. 1971, 19, 128-132. [CrossRef] 